son, Robert N. Dahlberg, has provided a beautiful plot of ground for the family, and where the son, John P., had been laid away before them.

Father and Mother Dahlberg and the other members of the family who have passed over to the great hereafter have gone with a blessed assurance of a glorious immortality.

The only surviving members of the company that crossed the Mississippi on September 13, 1845, are Robert Nelson Dahlberg, five years old at the time, who still maintains his residence at Keosauqua, although of recent years much of his time has been spent on the Pacific coast and the coast of the Gulf of Mexico, and Charlotte G. Dahlberg Mort of Hill City, Kansas, two years old at the time.

\title{
FOUNDING OF LEANDER CLARK COLLEGE
}

The first authoritative steps toward the founding of what is now Leander Clark College was taken by the Iowa Annual Conference at its session in Muscatine in August, 1855. At this time a board of trustees was appointed and empowered to take such measures looking toward the establishment of a college as might be deemed expedient. The board finally accepted an offer from the people of Shueyville to donate lands and some money on condition that the college be located in that neighborhood. Acting on this proposition a site on the open prairie was selected in January, 1856 , and in the following summer a college building was erected. The name "Western" was given to the new college because it was the farthest west of the schools of the United Brethren Church; the same name was given to the village that grew up around the college. The doors of the college swung open to receive students for the first time in January, 1857. At this time thirty-eight students offered themselves for enrollment. The faculty consisted of Rev. Solomon Weaver, president, and S. S. Dillman, M. A., J. C. Schrader, and Mrs. S. S. Dillman, teachers. It was seven years before the college sent out its first graduate.From minutes of the Iowa State Conference of the United Brethren in Christ; second annual session, 1910, p. 52. 
Copyright of Annals of Iowa is the property of State of Iowa, by \& through the State Historical Society of Iowa and its content may not be copied or emailed to multiple sites or posted to a listserv without the copyright holder's express written permission. However, users may print, download, or email articles for individual use. 